\title{
Co-expression of Mesothelin and CA125/MUC16 Is a Prognostic Factor for Breast Cancer
}

Takahiro Einama ( $\square$ einama0722@ndmc.ac.jp)

National Defense Medical College: Boei lka Daigakko https://orcid.org/0000-0002-4434-0803

Yoji Yamagishi

National Defense Medical College: Boei Ika Daigakko

Yasuhiro Takihata

National Defense Medical College: Boei Ika Daigakko

Takafumi Suzuki

National Defense Medical College: Boei Ika Daigakko

Tamio Yamasaki

National Defense Medical College: Boei Ika Daigakko

Yuichi Hirose

National Defense Medical College: Boei Ika Daigakko

Kazuki Kobayashi

National Defense Medical College: Boei lka Daigakko

Naoto Yonamine

National Defense Medical College: Boei Ika Daigakko

Ibuki Fujinuma

National Defense Medical College: Boei Ika Daigakko

Takazumi Tsunenari

National Defense Medical College: Boei Ika Daigakko

Makiko Koga

National Defense Medical College: Boei lka Daigakko

Yusuke Ishibashi

National Defense Medical College: Boei Ika Daigakko

Ken Nagata

National Defense Medical College: Boei Ika Daigakko

Takehiro Shiraishi

National Defense Medical College: Boei Ika Daigakko

Akiko Nakazawa

National Defense Medical College: Boei Ika Daigakko

Toshimitsu Iwasaki

National Defense Medical College: Boei Ika Daigakko

Eiji Shinto

National Defense Medical College: Boei Ika Daigakko

Kimi Kato

National Defense Medical College: Boei Ika Daigakko

\section{Kimiya Sato}

National Defense Medical College: Boei Ika Daigakko

\section{Hideki Ueno}

National Defense Medical College: Boei Ika Daigakko

Yoji Kishi

National Defense Medical College: Boei Ika Daigakko

Hitoshi Tsuda

National Defense Medical College: Boei Ika Daigakko

\section{Research}

Keywords: Breast cancer, Mesothelin, CA125/MUC16, Co-expression

Posted Date: June 7th, 2021

DOl: https://doi.org/10.21203/rs.3.rs-529914/v1 


\section{Abstract}

Background: The expression of mesothelin correlates with a poor prognosis in patients with breast cancer. Since mesothelin plays a role in cancer metastasis in association with CA125, we herein examined the clinicopathological significance and prognostic implications of the co-expression of mesothelin and CA125 in breast cancer.

Methods: The expression of mesothelin and CA125 was immunohistochemically examined in tissue samples collected from 478 breast cancer patients. The expression of these two molecules in more than $1 \%$ of tumor cells was defined as positive. The relationships between the co-expression of mesothelin and CA125, clinicopathological parameters, and clinical outcomes were analyzed by the chi-squared test and Cox's univariate and multivariate proportional hazard model analyses.

Results: Among 478 patients, mesothelin and CA125 were co-expressed in 48 (10\%), mesothelin only in 75 (16\%), CA125 only in 217 (45\%), and neither in 234 (49\%). A strong correlation was observed between the expression of mesothelin and CA125 $(P=0.0004)$. The co-expression of mesothelin and CA125 correlated with unfavorable patient relapse-free survival (RFS) $(P=0.0001)$ and was identified as an independent predictor of RFS by Cox's multivariate analysis.

Conclusion: This is the first study to demonstrate the prognostic significance of the co-expression of mesothelin and CA125 in breast cancer. The coexpression of these two molecules may play a significant role in the acquisition of aggressive clinical behavior.

\section{Introduction}

Mesothelin (MSLN) is a 40-kDa cell surface glycoprotein that is expressed by normal mesothelial cells, which line the surface of the pleura, pericardium, and peritoneum $(1,2)$. It is also expressed in various types of malignant tumors, including malignant mesothelioma, ovarian cancer, and pancreatic cancer(3-6). The full-length human MSLN gene primarily encodes a 71-kDa precursor protein, which may be physiologically cleaved by several furin-like proteases into a membrane-bound 40-kDa C-terminal fragment and a 31-kDa N-terminal fragment that is secreted into the blood(2). The C-terminal 40-kDa fragment, named MSLN, is attached to the cell membrane through a glycosyl-phosphatidylinositol (GPI) anchor(2,7).

CA125/MUC16 (CA125) is another cell surface glycoprotein that is present on the normal mesothelial cells lining body cavities(8, 9). An increase in the cell surface expression of CA125 has been reported in ovarian cancer and mesothelioma as well as in other cancers(8, 10-12). Due to its shedding into the blood circulation, serum CA125 is commonly measured to monitor disease progression in ovarian cancer patients and is also elevated in mesothelioma as well as under specific benign conditions(13-15). The gene encoding the peptide moiety of CA125 has been cloned and termed MUC16 because it shares characteristics associated with mucin proteins $(16,17)$.

MSLN may be one of the binding partners for CA125(18-21). Heterotypic adhesion through the high-affinity interaction between MSLN and CA125 may facilitate peritoneal metastasis from ovarian cancer $(18,20)$. However, the significance of the co-expression of MSLN and CA125 in breast cancer tissues currently remains unknown.

A correlation has been reported between the expression of MSLN and worse clinical outcomes in various cancer types(6, 21-23). We previously demonstrated that the expression of MSLN correlated with an aggressive tumor subtype and poor prognosis in patients with breast cancer(24). In the present study, we investigated the status of MSLN and CA125 expression in breast cancer by immunohistochemistry and examined the relationship between the co-expression of these two molecules and clinicopathological parameters, including patient relapse-free survival (RFS).

\section{Materials And Methods}

Patient Demographics and Tumor Specimens

The present study was performed with the approval of the Internal Review Board on ethical issues of the National Defense Medical College, Tokorozawa, Japan. Subjects comprised 478 patients who underwent surgery with curative intent for primary breast cancer between January 2002 and December 2012 at the Department of Surgery, National Defense Medical College Hospital. The clinicopathological parameters of these cases are summarized in Table 1.

Mean patient age was 59.2 ( \pm 0.5 standard deviation [SD]) years. Four hundred and seventy-five patients ( $99.4 \%$ ) were women, and the remaining 3 (0.6\%) were men. The nuclear grade (NG) was classified according to General Rules for Clinical and Pathological Recording of Breast Cancer, 18 ${ }^{\text {th }}$ edition(25). Estrogen and progesterone receptors were assessed by immunohistochemistry and defined as positive based on immunoreactivity in $1 \%$ or more of constituent carcinoma cells(26). Judgments on human epidermal growth factor receptor 2 were made according to the American Society of Clinical Oncology/College of American Pathologists guidelines 2013(27). The Ki-67 labeling index (LI) was assessed according to the recommendations of the Breast Cancer Working Group(28), and was defined as high when $14 \%$ or more of constituent carcinoma cells were immunoreactive(29). Pathological T and N factors and stages were graded by the clinical and pathological findings of breast cancer according to UICC $8^{\text {th }}$ edition. The median follow-up period was 94.0 months (range: 1.0 to 196.7 months). Fifty-three patients were lost to the follow-up, 71 relapsed, 59 had distant metastasis, and 32 died of breast cancer.

\section{Immunohistochemistry}

Formalin-fixed paraffin-embedded tissue blocks from 478 patients were collected from the archives of the Pathology Section, Department of Clinical Laboratories, National Defense Medical College Hospital. Tissue microarrays containing two representative tissue cores with a diameter of 2 mm for each case were constructed using a tissue microarrayer (Azumaya, Tokyo, Japan). Four-micrometer-thick sections were cut from these tissue microarray blocks and 
mounted on charged glass slides, deparaffinized, and rehydrated through a graded series of ethanol. Dako Target Retrieval Solution pH 9.0 (catalog no. S2368; Dako, Carpinteria, CA, USA) was used for antigen retrieval, and slides were boiled in a pressure cooker (Pascal Pressure Cooker, model S2800; Dako) at $125^{\circ} \mathrm{C}$ for 3 minutes. Sections were treated with $0.3 \%$ hydrogen peroxide for 5 minutes to block endogenous peroxidase activity. One slide for each section was then incubated with a mouse monoclonal antibody against MSLN (clone 5B2 diluted 1:50; Novocastra, Newcastle Upon Tyne, UK), and the other with a mouse monoclonal antibody against CA125 (clone M11 diluted 1:50; Dako) at room temperature for 30 minutes. They were reacted with a dextran polymer reagent combined with secondary antibodies and peroxidase (Envision/HRP; Dako) at room temperature for 30 minutes. Specific antigen-antibody reactions were visualized with $0.2 \%$ diaminobenzidine tetrahydrochloride and hydrogen peroxide. Slides were counterstained with hematoxylin for 10 minutes and then gently rinsed in reagent quality water.

Immunohistochemical Evaluation

All assessments were performed on the tumor region of the specimen (×200). Each slide was evaluated independently by 2 observers (T.E., Y.Y.) who were blinded to clinical outcomes. Immunostaining for MSLN and CA125 was assessed for both the staining proportion and intensity of tumor cells in each case. MSLN and CA125 expression levels were measured based on the percentage of cells showing the expression of each molecule as follows: $<1 \%, 1 \%<10 \%, 10 \%$ $<50 \%$, and $\geq 50 \%$. The intensities of the MSLN and CA125 immunoreactions were evaluated using the following scoring system: $1+$, incomplete membrane staining and/or faint or barely perceptible cytoplasmic staining in tumor cells; $2+$, the entire circumference of the cell membrane was stained and/or cytoplasmic staining exhibited moderate to strong staining. Cytoplasmic granular staining was also scored as 2+ (Fig. 1). The expression of MSLN and CA125 was positive when immunoreactivity was observed in $1 \%$ or more of tumor cells, irrespective of the intensity of immunoreactions, and negative when immunoreactivity was detected in less than $1 \%$ of cancer cells or was absent. Co-expression was positive when the expression of both MSLN and CA125 was detected, and was negative when the expression of MSLN, CA125, or both was absent.

\section{Statistical Analysis}

We used the $X^{2}$ test, Fisher's exact test, and the non-parametric Wilcoxon and Kruskal-Wallis tests to examine the relationships between the co-expression of MSLN and CA125 and clinicopathological parameters. Survival curves were drawn using the Kaplan-Meier method. Differences in survival curves were analyzed by the Log-rank test. The prognostic implications of the expression of MSLN and CA125 and other clinicopathological parameters were analyzed by Cox's univariate and multivariate proportional hazards models. All differences were considered to be significant at $P<0.05$. All statistical analyses were performed using JMP® 14 (SAS Institute Inc., Cary, NC, USA).

\section{Results}

Co-expression of MSLN and CA125 in Breast Cancer

The expression of MSLN was positive in carcinoma cells in 75 (15.7\%) out of 478 breast cancer specimens, while the expression of CA125 was positive in 217 (45.4\%) out of 478 specimens and in 48 (64.0\%) out of 75 MSLN-positive specimens. Among 403 MSLN-negative cases, the expression of CA125 was positive in 169 cases and negative in 234. A correlation was observed between the expression of MSLN and CA125 $(P=0.0004)($ Table 2).

The positive expression of MSLN correlated with the pathological T factor $(P=0.030)$, triple-negative subtype $(P<0.0001)$, NG3 $(P<0.0001)$, a higher Ki-67 LI $(P=0.0004)$, and higher relapse rate $(P=0.048)$. The positive expression of CA125 also correlated with the subtype $(P=0.0028)$ and a higher relapse rate $(P=$ 0.045) (Table 3).

The co-expression of MSLN and CA125 was detected in 48 cases $(10.0 \%)$ and correlated with the pathological T factor $(P=0.049)$, triple-negative subtype $(P<$ $0.0001)$, NG3 $(P<0.0001)$, a higher Ki-67 LI $(P=0.0008)$, and higher relapse rate $(P=0.0022)$ (Table 3$)$.

Clinical Analysis

Figure 2 shows the survival curves of 478 patients stratified by the MSLN and CA125 expression status of tumors. The RFS rate was significantly lower in patients with breast cancer expressing MSLN or CA125 than in those with breast cancer not expressing MSLN or CA125. Moreover, the prognosis of the group showing the co-expression of MSLN and CA125 was the poorest. Cox's univariate proportional hazards model analyses identified the pathological T factor, $\mathrm{NG}$, lymphatic invasion, $\mathrm{Ki}-67 \mathrm{LI}$, and pathological $\mathrm{N}$ factor as significant risk factors for recurrence. Consistent with previous findings(24), the expression of MSLN was identified as a significant risk factor for recurrence (Hazard ratio (HR) 1.89, 95\% confidence interval $(\mathrm{Cl})=1.06-3.18, P=0.0313$ ). In the present study, the expression of CA125 was identified as a significant risk factor for recurrence (HR $=1.67,95 \% \mathrm{Cl} 1.04-2.68, P=0.0319)$, while its co-expression with MSLN was a significantly stronger risk factor $(\mathrm{HR}=2.94,95 \% \mathrm{Cl} 1.60-5.06, P=0.0009)$.

In Cox's multivariate analyses, to exclude the possible effects of confounding factors, the multivariate analysis was performed including age, the pathological T factor, NG, lymphatic invasion, Ki-67 LI, and the pathological N factor with the expression of MSLN, CA125, or MSLN and CA125. The co-expression of MSLN and CA125 was identified as an independent predictor of RFS in breast cancer patients ( $\mathrm{HR}=1.92,95 \% \mathrm{Cl} 1.01-3.46, P=0.0483)$ as well as the pathological T factor $(\mathrm{HR}=2.26,95 \% \mathrm{Cl} 1.31-4.08, P=0.0032)$ and pathological $\mathrm{N}$ factor $(\mathrm{HR}=2.45,95 \% \mathrm{Cl} 1.43-4.28, P=0.0009)(\mathrm{Table} 4)$.

Figure 3 shows the survival curves of 333 patients with hormone receptor (HR)-positive, HER2-negative breast cancer stratified by the MSLN and CA125 expression status of tumors. The RFS rate was significantly lower in patients with breast cancer expressing MSLN than in those with breast cancer not expressing MSLN $(P=0.0021)$. In contrast, the RFS rate was slightly lower in patients with breast cancer expressing CA125 than in those with breast cancer not expressing CA125 $(P=0.057)$. The prognosis of the group with the co-expression of MSLN and CA125 was the poorest. Cox's univariate and multivariate analyses were performed on 333 luminal-type cases (Table 5). The expression of MSLN was identified as a significant risk factor for recurrence (HR 3.16,

Page $4 / 15$ 
$95 \% \mathrm{Cl} 1.36-6.54, P=0.010)$. In luminal-type patients, the expression of $\mathrm{CA} 125$ was not a significant risk factor for recurrence $(\mathrm{HR}=1.80,95 \% \mathrm{Cl} 0.97-3.37, P=$ 0.0606); however, its co-expression with MSLN and CA125 was identified as a significant risk factor ( $\mathrm{HR}=5.00,95 \% \mathrm{Cl} 1.87-11.2, P=0.0027)$. In the multivariate analysis, the expression of MSLN and its co-expression with CA125 were independent predictors of RFS in luminal-type breast cancer patients (Table 5).

\section{Discussion}

The present study investigated the clinicopathological implications of the co-expression of MSLN and CA125 in patients with breast cancer. The co-expression of MSLN and CA125, detected in $10 \%$ of patients with breast cancer, correlated with the pT, subtypes, grades, and Ki67 LI of primary tumors and a poorer patient prognosis, which suggested that the co-expression of these two molecules plays a significant role in the acquisition of aggressive clinical behavior by breast cancer.

We previously reported that the expression of MSLN correlated with tumor size, the subtype of breast cancer, higher NG and Ki-67 LI, and a higher relapse rate(24), which support findings on the expression of MSLN in pancreatic ductal adenocarcinoma, gastric cancer, extrahepatic bile duct cancer, and colorectal adenocarcinoma $(6,21-23,30,31)$. The expression of MSLN has potential as a prognostic marker in patients with invasive breast cancer(32, 33). Furthermore, among breast cancer subtypes, the expression of MSLN was found to be significantly more frequent in triple-negative breast cancer (TNBC) than in nonTNBC(34-37). Therefore, MSLN has potential as a novel immunotherapy target for TNBC; however, the relationship between its expression and patient prognosis remains controversial(34, 35, 37).

The present results demonstrated that the expression of MSLN correlated with that of CA125 in breast cancer. It is important to note that the patient group with breast cancer showing the co-expression of these two molecules had poorer RFS than those with high expression levels of MSLN or CA125 alone or low expression levels of MSLN and CA125. In the present study, the co-expression group more frequently had larger tumors, a higher NG, and higher Ki-67 LI, similar to the group with high MSLN expression levels, which correlated with recurrence. In ovarian and pancreatic cancers, the co-expression of MSLN and CA125 was previously found to be more frequent in the patient group with a more advanced clinical stage, higher histological grade, and worse clinical outcome $(20,21,38)$. These findings indicate that the co-expression of these two molecules promotes tumor development and metastasis, leading to a poorer prognosis.

The functional properties of the co-expression signaling pathway have not yet been elucidated in detail. CA125 was identified as an MSLN ligand, and the binding of CA125 to MSLN has been shown to induce cell-to-cell adhesion in these cancer cells(18). Mizukami reported that sherbet-like aggregates of cancer cells that are biologically active, but have not formed a gross tumor mass, were only present in the patient group treated with amatuximab, a chimeric anti-MSLN monoclonal antibody(39). This effect is consistent with the anti-tumor activity of amatuximab, which utilizes immune-effector cells to kill antibodybound cells via antibody-dependent cellular cytotoxicity and suppresses heterotypic cell formation to its cognate receptor on neighboring cells via the blockade of MSLN (39). Co-expression has been linked to the activation of both the AKT and ERK1/2 signaling pathways and has also been implicated in the metastatic growth and dissemination of cancer cells(40-43). Similar to other GPI-anchored proteins, MSLN requires CA125 and/or utilizes other receptors for intracellular signaling.

The binding interaction between MSLN and CA125 also selectively stimulates matrix metalloproteinase (MMP)-7, but not MMP-2 or MMP-9, in pancreatic cancer cells, which offers a novel perspective into the poor prognosis associated with their co-expression and the activation of MMP-7(44). MMP-7 is overexpressed in many tumors and may play an important role in tumor pathogenesis $(45,46)$. MMP-7 is a biomarker of fibrosis in the liver( 47,48$)$ and the lungs(49). Koyama et al. reported the attenuation of cholestatic liver fibrosis in mice homozygous for the mesothelin gene mutation, mesothelin (-/-) mice, and/or CA125 (-/-) mice, indicating the potential of MSLN as a target for antifibrotic therapy(50).

In conclusion, we herein demonstrated the clinicopathological significance of the co-expression of MSLN and CA125 in breast cancer, particularly in the luminal type, as an independent prognostic factor. An immunohistochemical examination of the expression of MSLN and CA125 in surgically resected tumor specimens may be clinically useful for prognostication after surgical therapy in patients with breast cancer.

\section{Declarations}

\section{Acknowledgments}

The authors would like to thank Ms. Hanae Fujishiro for her secretarial work.

Ethics approval and consent to participate: The study was approved by the institutional review board of National Defense Medical College.

Consent for publication: Not applicable.

Availability of data and materials: Datasets used and/or analyzed during this study are available from the corresponding author on reasonable request.

Competing interests: The authors declare that they have no competing interests.

Funding: Data extraction and data analysis was supported in part by JSPS KAKENHI Grant Number JP 18K15295. JSPS did not influence the study design, the data collection, the data analysis, the interpretation of data and the writing of the manuscript.

Authors' contributions: TE, YY, and HT performed the planning, acquisition of data, analysis of data, and writing of the manuscript. YT, TS, TY, YH, KK, NY, IF, TT, MK, YI, and YK acquired clinical data, KN, TS and ES acquired pathological data, and AN, TI, KK and KS conducted tumoral mesothelin and CA125 data 
acquisition and data analysis. HU substantively revised the draft. All authors substantively revised the draft. All authors read and approved the final manuscript.

\section{References}

1. Chang K, Pai LH, Pass H, Pogrebniak HW, Tsao MS, Pastan I, et al. Monoclonal antibody K1 reacts with epithelial mesothelioma but not with lung adenocarcinoma. Am J Surg Pathol. 1992;16(3):259-68. Epub 1992/03/01.

2. Chang K, Pastan I. Molecular cloning of mesothelin, a differentiation antigen present on mesothelium, mesotheliomas, and ovarian cancers. Proc Natl Acad Sci U S A. 1996;93(1):136-40. Epub 1996/01/09.

3. Argani P, lacobuzio-Donahue C, Ryu B, Rosty C, Goggins M, Wilentz RE, et al. Mesothelin is overexpressed in the vast majority of ductal adenocarcinomas of the pancreas: identification of a new pancreatic cancer marker by serial analysis of gene expression (SAGE). Clinical cancer research : an official journal of the American Association for Cancer Research. 2001;7(12):3862-8. Epub 2001/12/26.

4. Ordonez NG. Application of mesothelin immunostaining in tumor diagnosis. Am J Surg Pathol. 2003;27(11):1418-28. Epub 2003/10/25.

5. Ho M, Hassan R, Zhang J, Wang QC, Onda M, Bera T, et al. Humoral immune response to mesothelin in mesothelioma and ovarian cancer patients. Clinical cancer research : an official journal of the American Association for Cancer Research. 2005;11(10):3814-20. Epub 2005/05/18.

6. Einama T, Homma S, Kamachi H, Kawamata F, Takahashi K, Takahashi N, et al. Luminal membrane expression of mesothelin is a prominent poor prognostic factor for gastric cancer. Br J Cancer. 2012;107(1):137-42. Epub 2012/05/31.

7. Hassan R, Bera T, Pastan I. Mesothelin: a new target for immunotherapy. Clinical cancer research : an official journal of the American Association for Cancer Research. 2004;10(12 Pt 1):3937-42. Epub 2004/06/26.

8. Bast RC, Jr., Feeney M, Lazarus H, Nadler LM, Colvin RB, Knapp RC. Reactivity of a monoclonal antibody with human ovarian carcinoma. J Clin Invest. 1981;68(5):1331-7. Epub 1981/11/01.

9. Kabawat SE, Bast RC, Jr., Bhan AK, Welch WR, Knapp RC, Colvin RB. Tissue distribution of a coelomic-epithelium-related antigen recognized by the monoclonal antibody OC125. Int J Gynecol Pathol. 1983;2(3):275-85. Epub 1983/01/01.

10. Bateman AC, al-Talib RK, Newman T, Williams JH, Herbert A. Immunohistochemical phenotype of malignant mesothelioma: predictive value of CA125 and HBME-1 expression. Histopathology. 1997;30(1):49-56. Epub 1997/01/01.

11. Fuith LC, Daxenbichler G, Dapunt O. CA 125 in the serum and tissue of patients with gynecological disease. Arch Gynecol Obstet. 1987;241(3):157-64. Epub 1987/01/01.

12. Kushitani K, Takeshima Y, Amatya VJ, Furonaka O, Sakatani A, Inai K. Immunohistochemical marker panels for distinguishing between epithelioid mesothelioma and lung adenocarcinoma. Pathol Int. 2007;57(4):190-9. Epub 2007/02/24.

13. Baratti D, Kusamura S, Martinetti A, Seregni E, Oliva DG, Laterza B, et al. Circulating CA125 in patients with peritoneal mesothelioma treated with cytoreductive surgery and intraperitoneal hyperthermic perfusion. Ann Surg Oncol. 2007;14(2):500-8. Epub 2006/12/08.

14. Bast RC, Jr., Badgwell D, Lu Z, Marquez R, Rosen D, Liu J, et al. New tumor markers: CA125 and beyond. Int J Gynecol Cancer. 2005;15 Suppl 3:274-81. Epub 2005/12/14.

15. Simsek H, Kadayifci A, Okan E. Importance of serum CA 125 levels in malignant peritoneal mesothelioma. Tumour Biol. 1996;17(1):1-4. Epub 1996/01/01.

16. O'Brien TJ, Beard JB, Underwood LJ, Shigemasa K. The CA 125 gene: a newly discovered extension of the glycosylated N-terminal domain doubles the size of this extracellular superstructure. Tumour Biol. 2002;23(3):154-69. Epub 2002/09/10.

17. Yin BW, Lloyd KO. Molecular cloning of the CA125 ovarian cancer antigen: identification as a new mucin, MUC16. J Biol Chem. 2001;276(29):27371-5. Epub 2001/05/23.

18. Gubbels JA, Belisle J, Onda M, Rancourt C, Migneault M, Ho M, et al. Mesothelin-MUC16 binding is a high affinity, N-glycan dependent interaction that facilitates peritoneal metastasis of ovarian tumors. Mol Cancer. 2006;5(1):50. Epub 2006/10/28.

19. Kaneko O, Gong L, Zhang J, Hansen JK, Hassan R, Lee B, et al. A binding domain on mesothelin for CA125/MUC16. J Biol Chem. 2009;284(6):3739-49. Epub 2008/12/17.

20. Rump A, Morikawa Y, Tanaka M, Minami S, Umesaki N, Takeuchi M, et al. Binding of ovarian cancer antigen CA125/MUC16 to mesothelin mediates cell adhesion. J Biol Chem. 2004;279(10):9190-8. Epub 2003/12/17.

21. Einama T, Kamachi H, Nishihara H, Homma S, Kanno H, Takahashi K, et al. Co-expression of mesothelin and CA125 correlates with unfavorable patient outcome in pancreatic ductal adenocarcinoma. Pancreas. 2011;40(8):1276-82. Epub 2011/07/22.

22. Kawamata F, Kamachi H, Einama T, Homma S, Tahara M, Miyazaki M, et al. Intracellular localization of mesothelin predicts patient prognosis of extrahepatic bile duct cancer. Int J Oncol. 2012;41(6):2109-18. Epub 2012/10/16.

23. Kawamata F, Homma S, Kamachi H, Einama T, Kato Y, Tsuda M, et al. C-ERC/mesothelin provokes lymphatic invasion of colorectal adenocarcinoma. J Gastroenterol. 2014;49(1):81-92. Epub 2013/03/21.

24. Suzuki T, Yamagishi Y, Einama T, Koiwai T, Yamasaki T, Fukumura-Koga M, et al. Membrane mesothelin expression positivity is associated with poor clinical outcome of luminal-type breast cancer. Oncology letters. 2020;20(5):193. Epub 2020/09/22.

25. Tsuda H, Akiyama F, Kurosumi M, Sakamoto G, Watanabe T. Establishment of histological criteria for high-risk node-negative breast carcinoma for a multi-institutional randomized clinical trial of adjuvant therapy. Japan National Surgical Adjuvant Study of Breast Cancer (NSAS-BC) Pathology Section. Jpn J Clin Oncol. 1998;28(8):486-91. Epub 1998/10/14. 
26. Hammond ME, Hayes DF, Dowsett M, Allred DC, Hagerty KL, Badve S, et al. American Society of Clinical Oncology/College Of American Pathologists guideline recommendations for immunohistochemical testing of estrogen and progesterone receptors in breast cancer. J Clin Oncol. 2010;28(16):278495. Epub 2010/04/21.

27. Wolff AC, Hammond ME, Hicks DG, Dowsett M, McShane LM, Allison KH, et al. Recommendations for human epidermal growth factor receptor 2 testing in breast cancer: American Society of Clinical Oncology/College of American Pathologists clinical practice guideline update. J Clin Oncol. 2013;31(31):39974013. Epub 2013/10/09.

28. Dowsett M, Nielsen TO, A'Hern R, Bartlett J, Coombes RC, Cuzick J, et al. Assessment of Ki67 in breast cancer: recommendations from the International Ki67 in Breast Cancer working group. J Natl Cancer Inst. 2011;103(22):1656-64. Epub 2011/10/01.

29. Cheang MC, Chia SK, Voduc D, Gao D, Leung S, Snider J, et al. Ki67 index, HER2 status, and prognosis of patients with luminal B breast cancer. J Natl Cancer Inst. 2009;101(10):736-50. Epub 2009/05/14.

30. Shiraishi T, Shinto E, Mochizuki S, Tsuda H, Kajiwara Y, Okamoto K, et al. Mesothelin expression has prognostic value in stage lotalota/lotalotalota colorectal cancer. Virchows Archiv : an international journal of pathology. 2019;474(3):297-307. Epub 2019/01/04.

31. Shiraishi T, Shinto E, Nearchou IP, Tsuda H, Kajiwara Y, Einama T, et al. Prognostic significance of mesothelin expression in colorectal cancer disclosed by area-specific four-point tissue microarrays. Virchows Archiv : an international journal of pathology. 2020;477(3):409-20. Epub 2020/02/29.

32. Wang L, Niu Z, Zhang L, Liu X, Wang X, Li F, et al. Clinicopathological significance of mesothelin expression in invasive breast cancer. The Journal of international medical research. 2012;40(3):909-16. Epub 2012/08/22.

33. Li YR, Xian RR, Ziober A, Conejo-Garcia J, Perales-Puchalt A, June CH, et al. Mesothelin expression is associated with poor outcomes in breast cancer. Breast cancer research and treatment. 2014;147(3):675-84. Epub 2014/09/07.

34. Bayoglu IV, Kucukzeybek BB, Kucukzeybek Y, Varol U, Yildiz I, Alacacioglu A, et al. Prognostic value of mesothelin expression in patients with triple negative and HER2-positive breast cancers. Biomedicine \& pharmacotherapy = Biomedecine \& pharmacotherapie. 2015;70:190-5. Epub 2015/03/18

35. Parinyanitikul N, Blumenschein GR, Wu Y, Lei X, Chavez-Macgregor M, Smart M, et al. Mesothelin expression and survival outcomes in triple receptor negative breast cancer. Clinical breast cancer. 2013;13(5):378-84. Epub 2013/07/03.

36. Tchou J, Wang LC, Selven B, Zhang H, Conejo-Garcia J, Borghaei H, et al. Mesothelin, a novel immunotherapy target for triple negative breast cancer. Breast Cancer Res Treat. 2012;133(2):799-804. Epub 2012/03/16.

37. Tozbikian G, Brogi E, Kadota K, Catalano J, Akram M, Patil S, et al. Mesothelin expression in triple negative breast carcinomas correlates significantly with basal-like phenotype, distant metastases and decreased survival. PloS one. 2014;9(12):e114900. Epub 2014/12/17.

38. Shimizu A, Hirono S, Tani M, Kawai M, Okada K, Miyazawa M, et al. Coexpression of MUC16 and mesothelin is related to the invasion process in pancreatic ductal adenocarcinoma. Cancer science. 2012;103(4):739-46. Epub 2012/02/11.

39. Mizukami T, Kamachi H, Fujii Y, Matsuzawa F, Einama T, Kawamata F, et al. The anti-mesothelin monoclonal antibody amatuximab enhances the antitumor effect of gemcitabine against mesothelin-high expressing pancreatic cancer cells in a peritoneal metastasis mouse model. Oncotarget. 2018;9(73):33844-52. Epub 2018/10/20.

40. Bharadwaj U, Marin-Muller C, Li M, Chen C, Yao Q. Mesothelin confers pancreatic cancer cell resistance to TNF-alpha-induced apoptosis through Akt/PI3K/NF-kappaB activation and IL-6/Mcl-1 overexpression. Molecular cancer. 2011;10:106. Epub 2011/09/02.

41. Chang MC, Chen CA, Chen PJ, Chiang YC, Chen YL, Mao TL, et al. Mesothelin enhances invasion of ovarian cancer by inducing MMP-7 through MAPK/ERK and JNK pathways. The Biochemical journal. 2012;442(2):293-302. Epub 2011/10/18.

42. Wang Y, Wang L, Li D, Wang HB, Chen QF. Mesothelin promotes invasion and metastasis in breast cancer cells. The Journal of international medical research. 2012;40(6):2109-16. Epub 2013/01/17.

43. Rao TD, Tian H, Ma X, Yan X, Thapi S, Schultz N, et al. Expression of the Carboxy-Terminal Portion of MUC16/CA125 Induces Transformation and Tumor Invasion. PloS one. 2015;10(5):e0126633. Epub 2015/05/13.

44. Chen SH, Hung WC, Wang P, Paul C, Konstantopoulos K. Mesothelin binding to CA125/MUC16 promotes pancreatic cancer cell motility and invasion via MMP-7 activation. Scientific reports. 2013;3:1870. Epub 2013/05/23.

45. Miao S, Zhou SY, Han CS, Zhang LN, Sun HB, Yang B. Clinicopathological significance of matrix metalloproteinase-7 protein expression in esophageal cancer: a meta-analysis. Drug design, development and therapy. 2015;9:3729-40. Epub 2015/08/01.

46. Jones LE, Humphreys MJ, Campbell F, Neoptolemos JP, Boyd MT. Comprehensive analysis of matrix metalloproteinase and tissue inhibitor expression in pancreatic cancer: increased expression of matrix metalloproteinase-7 predicts poor survival. Clinical cancer research : an official journal of the American Association for Cancer Research. 2004;10(8):2832-45. Epub 2004/04/23.

47. Huang CC, Chuang JH, Chou MH, Wu CL, Chen CM, Wang CC, et al. Matrilysin (MMP-7) is a major matrix metalloproteinase upregulated in biliary atresiaassociated liver fibrosis. Modern pathology : an official journal of the United States and Canadian Academy of Pathology, Inc. 2005;18(7):941-50. Epub 2005/02/08.

48. Irvine KM, Okano S, Patel PJ, Horsfall LU, Williams S, Russell A, et al. Serum matrix metalloproteinase 7 (MMP7) is a biomarker of fibrosis in patients with non-alcoholic fatty liver disease. Scientific reports. 2021;11(1):2858. Epub 2021/02/05.

49. Rosas IO, Richards TJ, Konishi K, Zhang Y, Gibson K, Lokshin AE, et al. MMP1 and MMP7 as potential peripheral blood biomarkers in idiopathic pulmonary fibrosis. PLoS medicine. 2008;5(4):e93. Epub 2008/05/02.

50. Koyama Y, Wang P, Liang S, Iwaisako K, Liu X, Xu J, et al. Mesothelin/mucin 16 signaling in activated portal fibroblasts regulates cholestatic liver fibrosis. The Journal of clinical investigation. 2017;127(4):1254-70. Epub 2017/03/14. 


\section{Tables}

Table 1 Clinicopathological parameters of 478 patients with breast cancer in the present study

\begin{tabular}{|c|c|c|}
\hline \multicolumn{2}{|l|}{ Parameter } & \multirow{2}{*}{$\begin{array}{l}\mathrm{N}=478(\%) \\
115(24.2)\end{array}$} \\
\hline Age & $\leq 50$ & \\
\hline & $>50$ & $363(75.8)$ \\
\hline \multirow[t]{4}{*}{ Pathological T factor } & pTis & $1(0.2)$ \\
\hline & pT1 & $263(55.0)$ \\
\hline & pT2 & $194(40.6)$ \\
\hline & pT3 & $20(4.2)$ \\
\hline \multirow[t]{4}{*}{ Pathological N factor } & NO & $300(63.0)$ \\
\hline & N1 & $123(25.6)$ \\
\hline & N2 & $34(7.0)$ \\
\hline & N3 & $21(4.4)$ \\
\hline \multirow[t]{4}{*}{ Pathological Stage } & 0 & $1(0.2)$ \\
\hline & I & $200(41.8)$ \\
\hline & ॥ & $221(46.2)$ \\
\hline & III & $56(11.7)$ \\
\hline \multirow[t]{4}{*}{ Subtype } & ER/PgR+ and HER2- & $333(70.0)$ \\
\hline & ER/PgR+ and HER2+ & $30(6.1)$ \\
\hline & HER2+ & $34(7.1)$ \\
\hline & TNBC & $81(16.8)$ \\
\hline \multirow[t]{2}{*}{ Lymphatic invasion } & Positive & $284(59.4)$ \\
\hline & Negative & 194(40.6) \\
\hline \multirow[t]{3}{*}{ Nuclear grade } & 1 & $117(24.5)$ \\
\hline & 2 & $140(29.3)$ \\
\hline & 3 & $221(46.2)$ \\
\hline \multirow[t]{2}{*}{ Ki-67 labeling index } & $\geq 14$ & $298(62.3)$ \\
\hline & $<14$ & $180(37.7)$ \\
\hline \multirow[t]{2}{*}{ Recurrence } & Yes & $71(13.0)$ \\
\hline & No & $407(87.0)$ \\
\hline
\end{tabular}

ER, ER, Estrogen receptor;

HER2, Human epidermal growth factor receptor 2;

PgR, Progesterone receptor;

TNBC, Triple-negative breast cancer

Table 2 Mesothelin and CA125 immunostaining in breast cancer 


\begin{tabular}{|llll|}
\hline \multicolumn{4}{|l|}{ No. of cases (\%) } \\
\hline & CA125 expression & \\
& Positive & Negative & Total \\
\hline Mesothelin expression & & & \\
\hline Positive & $48(64.0)$ & $27(36.0)$ & 75 \\
\hline Negative & $169(41.7)$ & $234(58.3)$ & 403 \\
\hline Total & 217 & 261 & 478 \\
\hline
\end{tabular}

$\chi^{2}$ test $P=0.0004$

Table 3. Clinicopathological parameters according to mesothelin and CA125 expression levels 


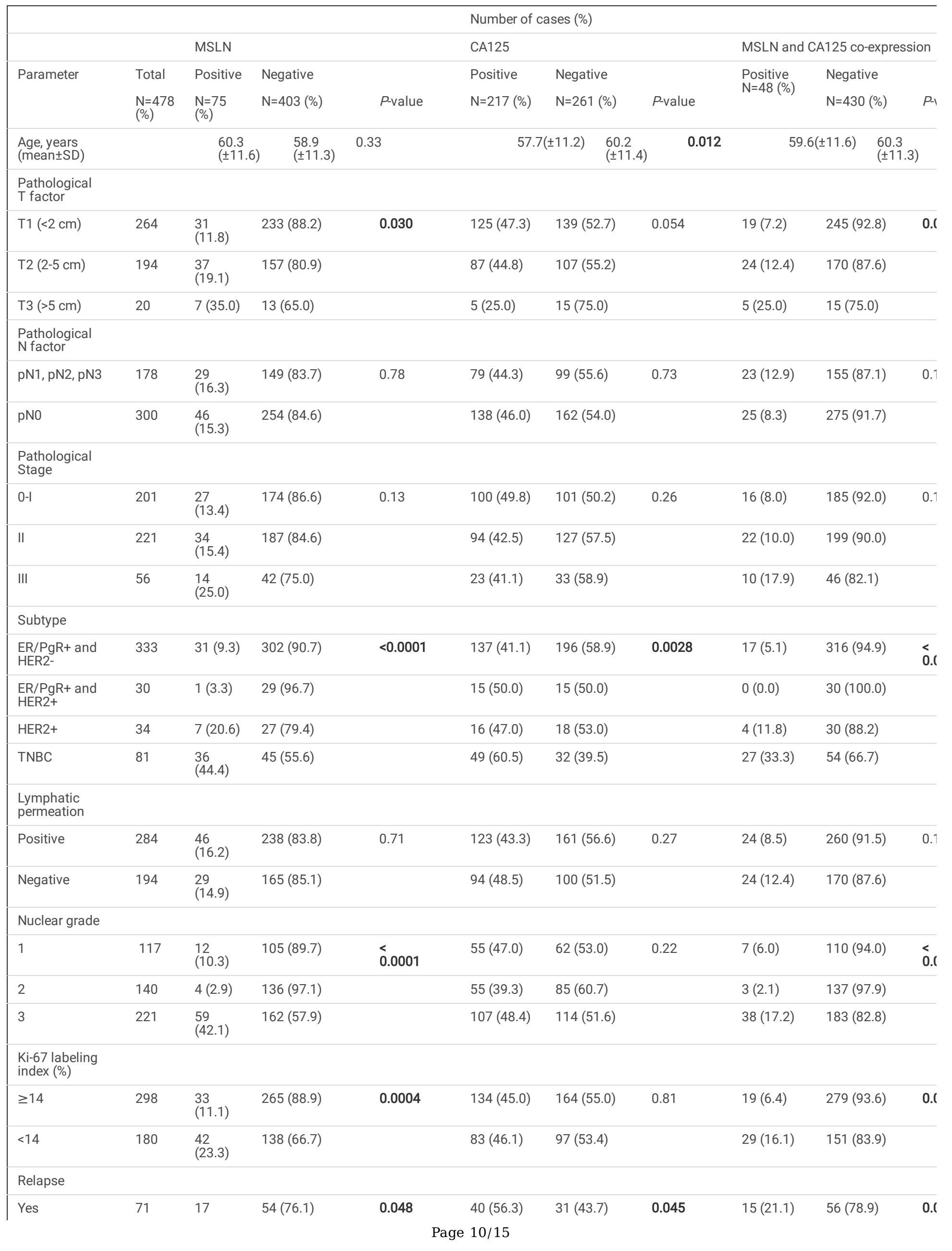


(23.9)

No

407

58

349 (85.7)

177 (43.5)

$230(56.5)$

$33(8.1)$

374 (91.9)

SD, standard deviation; ER, Estrogen receptor; PgR, Progesterone receptor; HER2, Human epidermal growth factor receptor 2; TNBC, Triple-negative breast cancer; MSLN; mesothelin

$X^{2}$ test.

Values in bold are significantly different.

Table 4 Cox's univariate and multivariate analyses for relapse in breast cancer patients 


\begin{tabular}{|c|c|c|c|c|c|c|c|c|}
\hline \multirow{3}{*}{$\begin{array}{l}\text { Parameter } \\
\text { (Favorable vs. } \\
\text { Unfavorable) }\end{array}$} & \multicolumn{2}{|c|}{ Univariate } & \multicolumn{6}{|l|}{ Multivariate } \\
\hline & \multirow[b]{2}{*}{$\begin{array}{l}\text { Hazard } \\
\text { ratio } \\
(95 \% \mathrm{Cl})\end{array}$} & \multirow[b]{2}{*}{$\begin{array}{l}P \text { - } \\
\text { value }\end{array}$} & \multicolumn{2}{|c|}{$\begin{array}{l}\text { Including mesothelin } \\
\text { expression }\end{array}$} & \multicolumn{2}{|c|}{$\begin{array}{l}\text { Including CA125 } \\
\text { expression }\end{array}$} & \multicolumn{2}{|c|}{$\begin{array}{l}\text { Including MSLN and CA125 co- } \\
\text { expression }\end{array}$} \\
\hline & & & $\begin{array}{l}\text { Hazard ratio } \\
(95 \% \mathrm{Cl})\end{array}$ & $P$-value & $\begin{array}{l}\text { Hazard } \\
\text { ratio } \\
(95 \% \mathrm{Cl})\end{array}$ & $\begin{array}{l}P \text { - } \\
\text { value }\end{array}$ & $\begin{array}{l}\text { Hazard ratio } \\
(95 \% \mathrm{Cl})\end{array}$ & $P$-value \\
\hline $\begin{array}{l}\text { Age } \\
(>50 \text { vs } \leq 50)\end{array}$ & $\begin{array}{l}1.04 \\
(0.59- \\
1.73)\end{array}$ & 0.0897 & & & & & & \\
\hline $\begin{array}{l}\text { Pathological T factor } \\
\text { (pT2, pT3 vs pTis, pT1) }\end{array}$ & $\begin{array}{l}3.69 \\
(2.22- \\
6.41)\end{array}$ & <. 0001 & $\begin{array}{l}2.33 \\
(1.35-4.18)\end{array}$ & 0.0020 & $\begin{array}{l}2.35 \\
(1.36-4.22)\end{array}$ & 0.0020 & $\begin{array}{l}2.26 \\
(1.31-4.08)\end{array}$ & 0.0032 \\
\hline $\begin{array}{l}\text { Nuclear grade } \\
(3 \text { vs. } 1,2)\end{array}$ & $\begin{array}{l}2.31 \\
(1.43- \\
3.82)\end{array}$ & 0.0005 & $\begin{array}{l}1.43 \\
(0.739-2.35)\end{array}$ & 0.197 & $\begin{array}{l}1.50 \\
(0.892- \\
2.58)\end{array}$ & 0.128 & $\begin{array}{l}1.39 \\
(0.81-2.42)\end{array}$ & 0.228 \\
\hline $\begin{array}{l}\text { Lymphatic invasion } \\
\text { (Positive vs. Negative) }\end{array}$ & $\begin{array}{l}2.39 \\
(1.38- \\
4.40)\end{array}$ & 0.0013 & $\begin{array}{l}1.34 \\
(0.747-2.56)\end{array}$ & 0.197 & $\begin{array}{l}1.34 \\
(0.744- \\
2.56)\end{array}$ & 0.336 & $\begin{array}{l}1.42 \\
(0.79-2.73)\end{array}$ & 0.247 \\
\hline $\begin{array}{l}\text { Ki-67 labeling index (\%) } \\
(\geq 14.0 \text { vs. }<14.0)\end{array}$ & $\begin{array}{l}1.62 \\
(1.00- \\
2.59)\end{array}$ & 0.0481 & $\begin{array}{l}1.25 \\
(0.753-2.07)\end{array}$ & 0.380 & $\begin{array}{l}1.28 \\
(0.774- \\
2.11)\end{array}$ & 0.332 & $\begin{array}{l}1.19 \\
(0.71-1.98)\end{array}$ & 0.507 \\
\hline $\begin{array}{l}\text { Pathological N factor } \\
\text { (pN1, pN2, pN3 vs. pN0) }\end{array}$ & $\begin{array}{l}3.76 \\
(2.31- \\
6.29)\end{array}$ & $\hat{0} .0001$ & $\begin{array}{l}2.61 \\
(1.54-4.54)\end{array}$ & 0.0003 & $\begin{array}{l}2.54 \\
(1.50-4.43)\end{array}$ & 0.0005 & $\begin{array}{l}2.45 \\
(1.43-4.28)\end{array}$ & 0.0009 \\
\hline $\begin{array}{l}\text { Estrogen receptor } \\
\text { (Positive vs Negative) }\end{array}$ & $\begin{array}{l}2.43 \\
(1.28- \\
3.39)\end{array}$ & 0.0037 & $\begin{array}{l}1.26 \\
(0.59-2.83)\end{array}$ & 0.548 & $\begin{array}{l}1.24 \\
(0.60-2.78)\end{array}$ & 0.566 & $\begin{array}{l}1.17 \\
(0.55-2.62)\end{array}$ & 0.697 \\
\hline $\begin{array}{l}\text { Progesterone receptor } \\
\text { (Positive vs Negative) }\end{array}$ & $\begin{array}{l}2.42 \\
(1.26- \\
3.21)\end{array}$ & 0.0038 & $\begin{array}{l}1.54 \\
(0.72-3.09)\end{array}$ & 0.256 & $\begin{array}{l}1.53 \\
(0.71-3.07)\end{array}$ & 0.267 & $\begin{array}{l}1.49 \\
(0.69-2.99)\end{array}$ & 0.296 \\
\hline $\begin{array}{l}\text { HER2 receptor } \\
\text { (Negative vs Positive) }\end{array}$ & $\begin{array}{l}0.96 \\
(0.50- \\
1.93)\end{array}$ & 0.91 & & & & & & \\
\hline $\begin{array}{l}\text { Mesothelin expression } \\
\text { (Positive vs. Negative) }\end{array}$ & $\begin{array}{l}1.89 \\
(1.06- \\
3.18)\end{array}$ & 0.0313 & $\begin{array}{l}1.34 \\
(7.38-2.35)\end{array}$ & 0.319 & & & & \\
\hline $\begin{array}{l}\text { CA125 expression } \\
\text { (Positive vs. Negative) }\end{array}$ & $\begin{array}{l}1.67 \\
(1.04- \\
2.68)\end{array}$ & 0.0319 & & & $\begin{array}{l}1.60 \\
(1.00-2.58)\end{array}$ & 0.0494 & & \\
\hline $\begin{array}{l}\text { MSLN and CA125 co- } \\
\text { expression } \\
\text { (Positive vs. Negative) }\end{array}$ & $\begin{array}{l}2.94 \\
(1.60- \\
5.06)\end{array}$ & 0.0009 & & & & & $\begin{array}{l}1.92 \\
(1.01-3.46)\end{array}$ & 0.0483 \\
\hline
\end{tabular}

$\mathrm{Cl}$, confidence interval

Table 5 Cox's univariate and multivariate analyses of relapse in 333 patients with luminal-type breast cancer 


\begin{tabular}{|c|c|c|c|c|c|c|}
\hline \multirow{3}{*}{$\begin{array}{l}\text { Parameter } \\
\text { (Favorable vs. Unfavorable) }\end{array}$} & \multicolumn{2}{|l|}{ Univariate } & \multicolumn{4}{|l|}{ Multivariate } \\
\hline & \multirow[b]{2}{*}{$\begin{array}{l}\text { Hazard ratio } \\
(95 \% \mathrm{Cl})\end{array}$} & \multirow[b]{2}{*}{$P$-value } & \multicolumn{2}{|c|}{ Including mesothelin expression } & \multicolumn{2}{|c|}{ Including MSLN and CA125 co-expression } \\
\hline & & & $\begin{array}{l}\text { Hazard ratio } \\
(95 \% \mathrm{Cl})\end{array}$ & $P$-value & $\begin{array}{l}\text { Hazard ratio } \\
(95 \% \mathrm{Cl})\end{array}$ & $P$-value \\
\hline $\begin{array}{l}\text { Age } \\
(\leq 50 \text { vs }>50)\end{array}$ & $\begin{array}{l}1.04 \\
(0.50-2.01)\end{array}$ & 0.919 & & & & \\
\hline $\begin{array}{l}\text { Pathological T factor } \\
\text { (pT2, pT3 vs pTis, pT1) }\end{array}$ & $\begin{array}{l}4.85 \\
(2.46-10.4)\end{array}$ & $<0.0001$ & $\begin{array}{l}2.93 \\
(1.44-6.47)\end{array}$ & 0.0027 & $\begin{array}{l}2.95 \\
(1.45-6.51)\end{array}$ & 0.0023 \\
\hline $\begin{array}{l}\text { Nuclear grade } \\
(3 \text { vs. } 1,2)\end{array}$ & $\begin{array}{l}1.61 \\
(0.78-3.75)\end{array}$ & 0.205 & & & & \\
\hline $\begin{array}{l}\text { Lymphatic invasion } \\
\text { (Positive vs. Negative) }\end{array}$ & $\begin{array}{l}1.55 \\
(0.84-2.92)\end{array}$ & 0.160 & & & & \\
\hline $\begin{array}{l}\text { Ki-67 labeling index }(\%) \\
(\geq 14.0 \text { vs. }<14.0)\end{array}$ & $\begin{array}{l}1.73 \\
(0.87-3.26)\end{array}$ & 0.110 & & & & \\
\hline $\begin{array}{l}\text { Pathological N factor } \\
\text { (pN1, pN2, pN3 vs. pN0) }\end{array}$ & $\begin{array}{l}6.65 \\
(3.30-14.9)\end{array}$ & $<0.0001$ & $\begin{array}{l}5.05 \\
(2.43-11.57)\end{array}$ & $<0.0001$ & $\begin{array}{l}4.79 \\
(2.32-11.0)\end{array}$ & $<0.0001$ \\
\hline $\begin{array}{l}\text { Mesothelin expression } \\
\text { (Positive vs. Negative) }\end{array}$ & $\begin{array}{l}3.16 \\
(1.36-6.54)\end{array}$ & 0.010 & $\begin{array}{l}2.96 \\
(1.25-6.26)\end{array}$ & 0.016 & & \\
\hline $\begin{array}{l}\text { CA125 expression } \\
\text { (Positive vs. Negative) }\end{array}$ & $\begin{array}{l}1.80 \\
(0.97-3.37)\end{array}$ & 0.061 & & & & \\
\hline $\begin{array}{l}\text { MSLN and CA125 co-expression } \\
\text { (Positive vs. Negative) }\end{array}$ & $\begin{array}{l}5.00 \\
(1.87-11.2)\end{array}$ & 0.0027 & & & $\begin{array}{l}3.46 \\
(1.28-7.90)\end{array}$ & 0.017 \\
\hline
\end{tabular}

$\mathrm{Cl}$, confidence interval

\section{Figures}




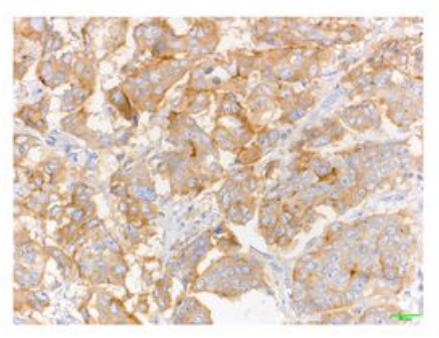

A

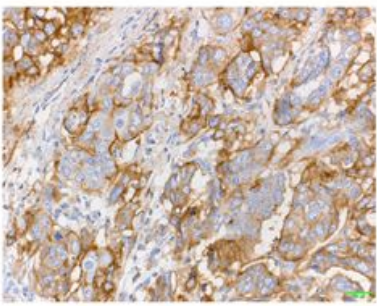

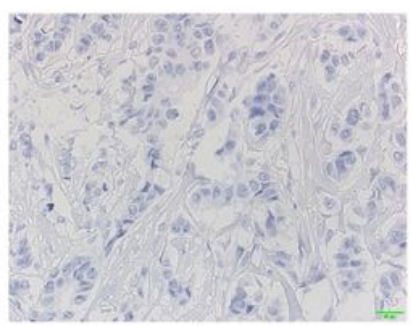

$c$

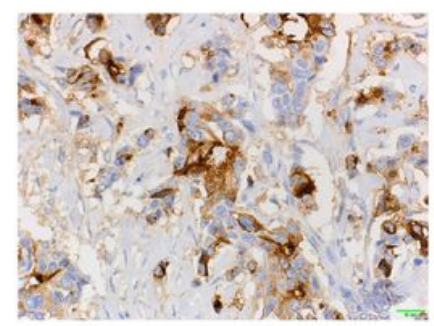

D

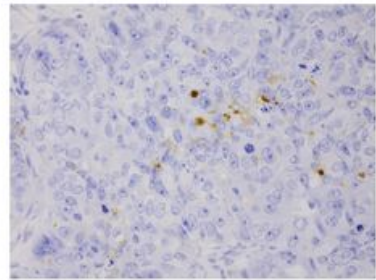

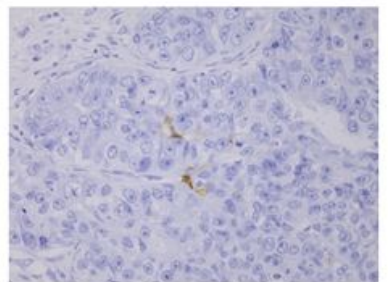

\section{Figure 1}

Representative cases of mesothelin and CA125 expression in breast cancer (A-F). Patient 1: Mesothelin (A) and CA125 (B) is diffusely positive in triplenegative breast cancer. Patient 2: Mesothelin was not expressed (C), whereas CA125 (D) was moderately to strongly expressed. Patient 3: The expression of mesothelin (E) and CA125 (F) was detected in the cytoplasm only in $<10 \%$ of cancer cells. Immunoperoxidase stain, original magnification $\times 400$.

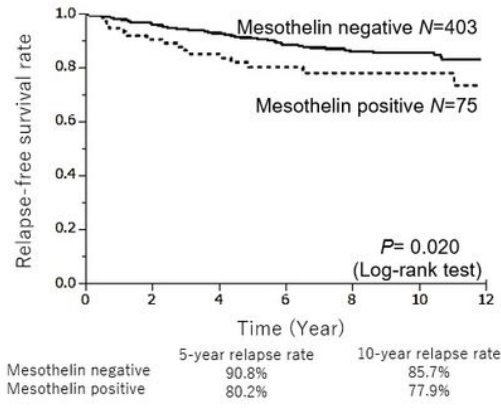

A

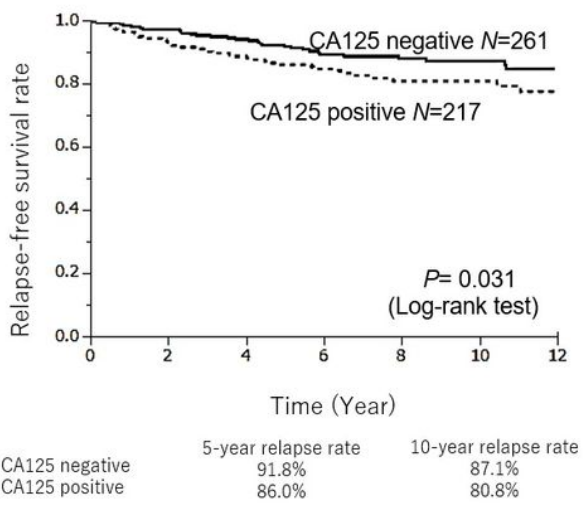

B

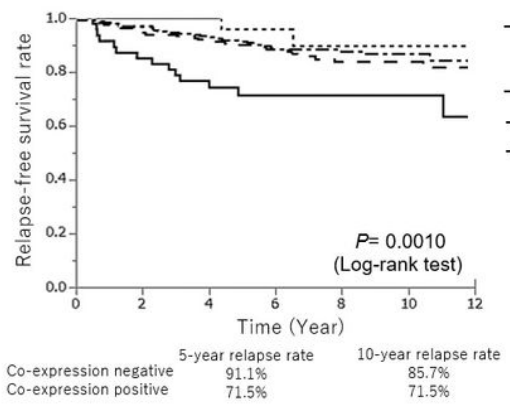

MSLN and CA125 positive $\mathrm{N}=48$

- . - MSLN and CA125 negative $\mathrm{N}=234$

--.- MSLN positive and $\mathrm{CA} 125$ negative $\mathrm{N}=27$

- MSLN negative and CA125 positive $\mathrm{N}=169$

\begin{tabular}{lll} 
Co-expression positive & $91.1 \%$ & $85.7 \%$ \\
\hline
\end{tabular} 
Figure 2

Relapse-free survival in patients with breast cancer after surgical therapy stratified by the status of the expression of mesothelin (A), CA125 (B), and mesothelin and CA125 (C). (A) The curve for the patient group with mesothelin-positive tumors was significantly different from that for the patient group with mesothelin-negative tumors (median RFS, 10.8 vs 12.0 years; $P=0.020$ ). (B) The curve for the patient group with CA125-positive tumors was significantly different from that for the patient group with CA125-negative tumors (median RFS was 11.3 vs 12.2 years in the CA125-negative expression group; $P$ = 0.031). (C) The curve for the patient group with tumors co-expressing mesothelin and CA125 was significantly different from that for the patient group with tumors not co-expressing these two molecules (MSLN- and CA125-negative N=234, MSLN-positive and CA125-negative N=27, MSLN-negative and CA125-positive $\mathrm{N}=169$ ) (median RFS was 9.9 vs 12.1 years; $\mathrm{P}=0.0001$ ).

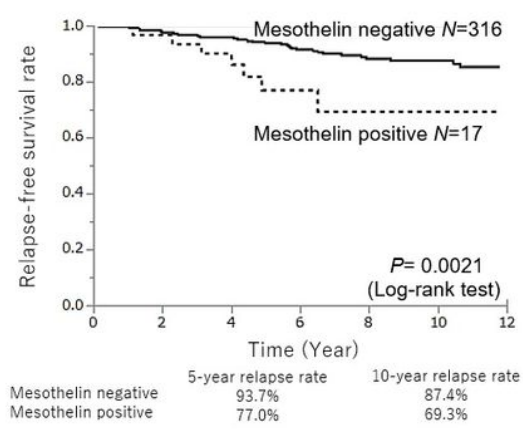

A

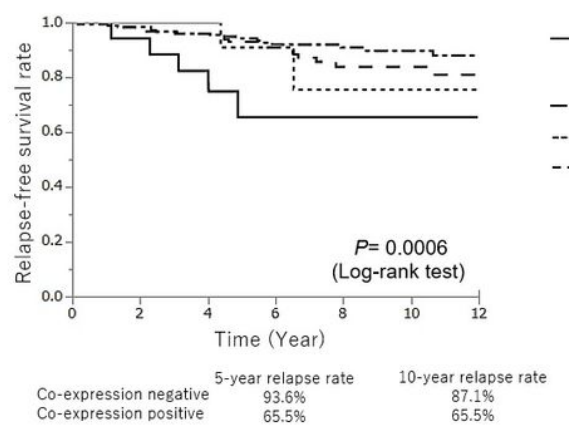

C

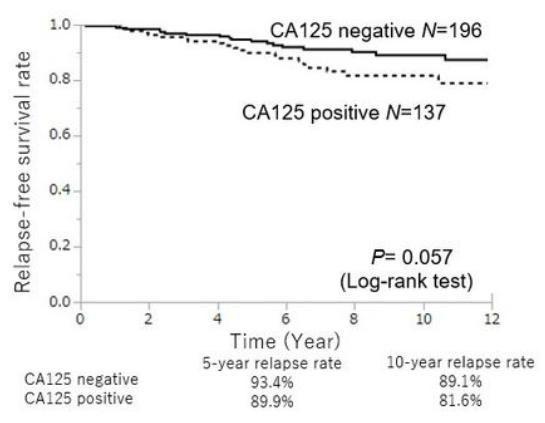

B

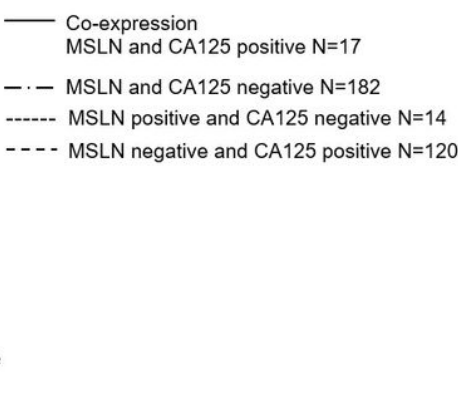

\section{Figure 3}

Relapse-free survival in luminal-type breast cancer patients after surgical therapy stratified by the status of the expression of mesothelin (A), CA125 (B), and mesothelin and CA125 (C). (A) The curve for the patient group with mesothelin-positive tumors was significantly different from that for the patient group with mesothelin-negative tumors (median RFS, 10.4 vs 12.3 years; $P=0.0021$ ). (B) The curve for the patient group with CA125-positive tumors was significantly different from that for the patient group with CA125-negative tumors (median RFS, 11.5 vs 12.5 years in the CA125-negative expression group; $\mathrm{P}=0.057$ ). (C) The curve for the patient group with tumors co-expressing mesothelin and CA125 was significantly different from that for the patient group with tumors not co-expressing these two molecules (MSLN- and CA125-negative N=182, MSLN-positive and CA125-negative N=14, MSLN-negative and CA125-positive N=120) (median RFS, 9.8 vs 12.2 years; $P=0.0006)$. 